\title{
THE FINTECH AND ISLAMIC FINANCE SYNTHESIS IN THE MODERN WORLD
}

\author{
Elvira Ildarovna Bulatova \\ $\mathrm{PhD}$ in Economics, Assistant Professor of Banking Department of the \\ Institute of Management, Economy and Finance, Kazan Federal University, \\ Kazan, Russia \\ E-mail: bulatovaei@yandex.ru
}

Ekaterina Alekseevna Potapova

Graduate student of Banking Department of the Institute of Management, Economy and Finance, Kazan Federal University, Kazan, Russia E-mail: potapovakate@gmail.com

Regina Andreevna Fathutdinova Master of the Institute of Management, Economy and Finance, Kazan Federal University, Kazan, Russia E-mail: yumio.moe@yandex.ru

Ruslan Ghirgishanovich Yandiev Master of the Institute of Management, Economy and Finance, Kazan Federal University, Kazan, Russia E-mail: ryandiev@gmail.com

Recepción: 05/08/2019 Aceptación: 16/09/2019 Publicación: 23/10/2019

\section{Citación sugerida:}

Bulatova, E.I., Potapova, E.A., Fathutdinova, R.A., y Yandiev, R.C. (2019). The fintech and islamic finance synthesis in the modern world. 3C TIC. Cuadernos de desarrollo aplicados a las TIC. Edición Especial, Octubre 2019, 258-273. doi: https://doi. org/10.17993/3ctic.2019.83-2.258-273

Suggested citation:

Bulatova, E.I., Potapova, E.A., Fathutdinova, R.A., \& Yandiev, R.C. (2019). The fintech and islamic finance synthesis in the modern world. 3C TIC. Cuadernos de desarrollo aplicados a las TIC. Special Issue, October 2019, 258-273. doi: https://doi. org/10.17993/3ctic.2019.83-2.258-273 


\section{ABSTRACT}

The article discusses the economic prerequisites for the effective growth of Islamic finance in modern conditions, analyzes the existing definitions of Islamic finance and banking and financial technologies, which served as the basis for the formation of a new definition of digital Islamic banking.

The authors carried out a simulation of the influence of the FinTech industry on the development of Islamic finance and formed the basic prerequisites for further sustainable growth in this area. The new theoretical definition is a synthesis of two systems that can be used later to identify digital tools that can be applied within the framework of Islamic finance. No less important in this aspect is the preservation of Sharia norms.

The modeling becomes an evidence base for the further use and expansion of Fintech tools in Islamic banking and Islamic finance in general. This aspect is also confirmed by the development of the Islamic Fintech Ecosystem and Islamic Fintech companies.

\section{KEYWORDS}

Islamic finance, Islamic banking, Financial technologies, Fintech, Economic and mathematical modeling, Digitalization, Islamic fintech, Digital islamic banking. 


\section{INTRODUCTION}

Today, the development of Islamic finance, expands the possibilities of the financial interrelationship between participants at the world level, and not only within the framework of the Islamic world. Nowadays, the rapid development of digital technologies within the pecuniary section actualizes the use of new tools in the countries of the Islamic world (Demyanova, 2017).

Today FinTech is gaining momentum in such areas as online lending, money transfers, credit ratings, crowdfunding, blockchain and cryptocurrency. In addition, some companies develop robot consultants who can offer solutions for deposits and lending, based on the wishes of customers, and taking into account all kinds of risks (Li et al., 2009).

For this purpose, this economic model was designed at define the strike of the development of pecuniary technologies upon the volume of Islamic finance (Bulatova, Zakhmatovm, Aliakberova, \& Koczar, 2016).

\section{METHODOLOGY}

The article provides a structural-dynamic analysis of GDP for the four countries and Dow Jones to determine more efficient cheap pickup into the nations of the Islamic world. qua in short of the lysis, the maners of correlation and regression analysis were applied in order to build a forecast of Islamic banking assets with the influence of financial technology factors on it (Fintech). The following methods were also used: statistical, graphical methods of analysis, tabulation, generalization and systematization, as well as methods of scientific knowledge. 


\section{RESULTS AND DISCUSSION}

In the context of global financial and geopolitical instability, a constant uncontrolled flow of capital between financial markets caused by speculative actions, factors arise to slow down the development of the national and world economy, such as price instability, high cost of borrowed funds, and inefficient redistribution of monetary resources (Patrutiu-Baltes, 2016).

In 2014-2018, despite the economic crisis in general, it is observed that qua in short of the reduction into petroleum values, not only the growth of assets of banks in the Islamic world, but also profitability is declining, which leads to a potential merger or takeover of financial institutions. However, to continue confronting crisis situations Islamic financial institutions need to turn to innovations and modern technologies used in the financial world (Jamaldeen, n.d.).

Most oil-producing countries have a stable legal structure that allows for the effective use of Islamic banking structures alongside traditional institutions. If the broader banking sector suffers from lower oil prices, it is expected that policies of both legal and regulatory nature will be formulated for the banking sector and not just for ordinary or Islamic banks. On the other hand, Islamic banks are inherently risk-averse. Given their ban on gambling, uncertainty and speculation, they are perhaps better protected to protect themselves from high risks and unstable investments (Islami Bank Bangladesh Limited, n.d.; Bloomberg, 2019; Lim, 2019).

While the Islamic finance sector shows a more stable performance during crisis turmoil in the global financial market in the GDP growth rate at constant prices in comparison to leading economies of the world (Figure 1). 

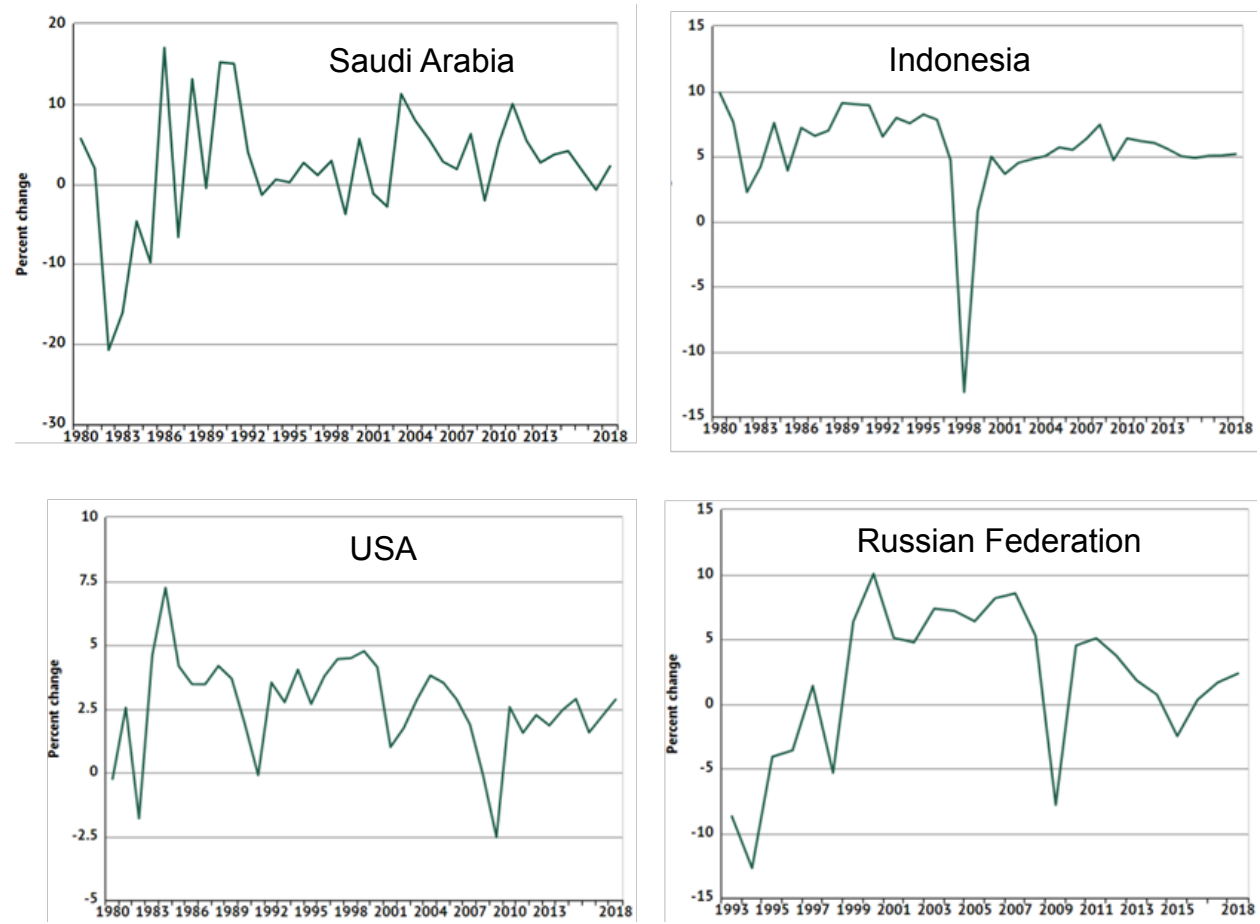

Figure 1. Comparison of GDP of countries in the world. Source: (World Data Atlas, n.d.)

In addition, the GDP growth rate showed positive dynamics, the index of Dow Jones from the Islamic world than USA rate (Figure 2).

Comparative characteristics of the Dow Jones indexes of the United States of America and the Islamic world showed that:

- The Dow Jones USA index for 10 years rose by $8.83 \%$

- The Dow Jones Islamic Market index rose by 16.47 in 10 years $\%$. 


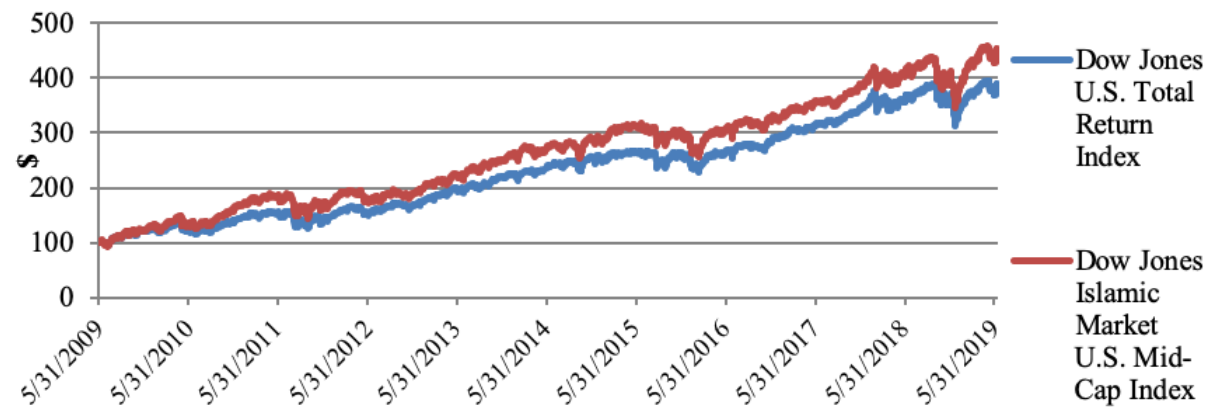

Figure 2. Comparison of the Dow Jones indices of the USA and the Islamic world. Source: (S\&P Dow Jones Indices, n.d.).

This structural-dynamic analysis shows a more sustainable growth of Islamic finance in comparison with western countries. Thus, an important aspect of the budgetary extension of the nations of the Islamic universe may be the efficacy of digital tools in the industry FinTech.

There are different interpretations in the definition of financial, technology and Islamic finance, the main of which are presented in Table 1.

Table 1. The financial technologies and Islamic finance definitions and interpretation.

\begin{tabular}{|c|c|c|}
\hline Definition & \multicolumn{1}{|c|}{ Interpretation } & $\begin{array}{c}\text { Supporters of } \\
\text { interpretation }\end{array}$ \\
\hline $\begin{array}{c}\text { Digital innovative financial services solutions } \\
\text { provided and used by companies on a technology } \\
\text { platform, competing / cooperating with financial } \\
\text { institutions. }\end{array}$ & E.A. Demianova \\
\hline $\begin{array}{c}\text { Financial } \\
\text { Technology }\end{array}$ & $\begin{array}{c}\text { It is strangely surprising how academic literature } \\
\text { has neglected the field despite the marvelous } \\
\text { impact of fiscal technology on the fiscal favors } \\
\text { industry. }\end{array}$ & Shim and Shin, 2016 \\
\hline & $\begin{array}{c}\text { It is driven by variations in the ecosystem } \\
\text { and contesting structure of favors and the } \\
\text { transformation of craft running, fiscal technology. }\end{array}$ & Deloitte, 2016 \\
\hline
\end{tabular}




\begin{tabular}{|c|c|c|}
\hline Definition & Interpretation & $\begin{array}{l}\text { Supporters of } \\
\text { interpretation }\end{array}$ \\
\hline \multirow{3}{*}{ Islamic finance } & $\begin{array}{l}\text { An ethical financial and investment sector serving } \\
\text { the needs of the real economy, which are based } \\
\text { on the principles of legality, justice, equality and } \\
\text { distribution. The basic economic principle is a ban } \\
\text { on usury }\end{array}$ & E. A. Baydaulet \\
\hline & $\begin{array}{l}\text { Islamic banking - The financial order, graded on } \\
\text { the origins of Islamic law and ushered by Islamic } \\
\text { economics, is called non-profit banking. }\end{array}$ & Sandra Lim \\
\hline & $\begin{array}{l}\text { It is Shari'a law that specifies how to finance it, } \\
\text { which is a financial system. }\end{array}$ & Faleel Jamaldeen \\
\hline Islamic banking & $\begin{array}{l}\text { Adherence to the Shari'a can create a kind of } \\
\text { Islamic banking system that can be used to develop } \\
\text { financial resources through its feasible usage } \\
\text { through the Islamic economy. }\end{array}$ & ING GROUP, 2017 \\
\hline \multirow[t]{2}{*}{ Islamic banking } & $\begin{array}{l}\text { Islamic Banking With the ethics of the Islamic value } \\
\text { system, essentially a normative concept is also } \\
\text { described as overseas banking. }\end{array}$ & Dr. Ziauddin Ahmed \\
\hline & $\begin{array}{l}\text { Islamic banking is a finance management system } \\
\text { that is based on the Islamic rules }\end{array}$ & Junaid Akhtar Abbasi \\
\hline \multirow[t]{2}{*}{ Digitalization } & $\begin{array}{c}\text { Digitizing comparability data encryption and } \\
\text { encryption is called digitalization, which allows } \\
\text { computers to supply, procedure, and broadcast } \\
\text { such data. }\end{array}$ & Jason Bloomberg \\
\hline & $\begin{array}{l}\text { With the integration of digital technologies } \\
\text { everything that can be digitized can be termed } \\
\text { digital. }\end{array}$ & Mohamed El-Shimy \\
\hline
\end{tabular}

Presents interpretations reveal the essence of Islamic finance and financial technologies as two unrelated directions. However, with the development and application of tools for the FinTech industry in the Islamic world is important for the formation of this definition, such as digital Islamic banking.

Digital Islamic banking is a technology of providing Islamic banking products and services through online services using tools FinTech industry.

An important aspect of the formation of the new definition is a close relationship between Islamic finance and Islamic banking since banks are an important element of the financial system. 
Considering the influx of FinTech industry invoices upon the enlargement of Islamic banking as an element of the financial system, economic and mathematical modeling was carried out. The indicators to be modeled are presented in Table 2.

Table 2. Input data for modulation.

\begin{tabular}{|c|c|c|c|c|c|c|c|}
\hline Years & $\begin{array}{c}\text { Islamic } \\
\text { Banking } \\
\text { Assets } \\
\text { (Billion USD) }\end{array}$ & $\begin{array}{l}\text { Total } \\
\text { investment } \\
\text { activity in } \\
\text { FinTech } \\
\text { (Capital } \\
\text { invested } \\
\text { (\$B)) }\end{array}$ & $\begin{array}{c}\text { Total } \\
\text { investment } \\
\text { activity in } \\
\text { FinTech } \\
\text { (Deal count) }\end{array}$ & $\begin{array}{l}\text { Global } \\
\text { venture } \\
\text { capital } \\
\text { activity in } \\
\text { FinTech with } \\
\text { corporate } \\
\text { participation } \\
\text { (Capital } \\
\text { invested } \\
\text { (\$B)) }\end{array}$ & $\begin{array}{l}\text { Global } \\
\text { venture } \\
\text { capital } \\
\text { activity in } \\
\text { FinTech with } \\
\text { corporate } \\
\text { participation } \\
\text { (Deal count) }\end{array}$ & $\begin{array}{c}\text { Global private } \\
\text { investment in } \\
\text { blockchain \& } \\
\text { cryptocurrency } \\
\text { (Capital } \\
\text { invested (\$B)) }\end{array}$ & $\begin{array}{l}\text { Global private } \\
\text { investment in } \\
\text { blockchain \& } \\
\text { cryptocurrency } \\
\text { (Deal count) }\end{array}$ \\
\hline & $\mathbf{Y}$ & $\mathrm{X} 1$ & $\mathrm{X} 2$ & X3 & X4 & $\times 5$ & X6 \\
\hline 2013 & 1565 & 18,9 & 1,132 & 0,8 & 102 & 0,2 & 69 \\
\hline 2014 & 1445 & 45,4 & 1,543 & 2,5 & 137 & 0,7 & 144 \\
\hline 2015 & 1604 & 67,1 & 1,925 & 8,5 & 225 & 0,5 & 134 \\
\hline 2016 & 1675 & 63,4 & 1,893 & 11,6 & 287 & 0,6 & 159 \\
\hline 2017 & 1721 & 50,8 & 2,165 & 10,3 & 327 & 4,8 & 218 \\
\hline $2018^{*}$ & 1809 & 111,8 & 2,196 & 23,1 & 357 & 4,5 & 494 \\
\hline
\end{tabular}

Source: (Pollari \& Ruddenklau, 2018).

Initially, a correlation matrix is created to specify the grade of penetration of the selected X on the studied Y (Table 3).

Table 3. Correlation matrix.

\begin{tabular}{|c|c|c|c|c|c|c|c|}
\hline & $\mathbf{Y}$ & $\mathrm{X} 1$ & $\mathrm{X} 2$ & X3 & X4 & $\times 5$ & X6 \\
\hline $\mathbf{Y}$ & 1 & & & & & & \\
\hline $\mathrm{X} 1$ & 0,704093 & 1 & & & & & \\
\hline $\mathrm{X} 2$ & 0,755271 & 0,793208 & 1 & & & & \\
\hline $\mathrm{X} 3$ & 0,886938 & 0,946588 & 0,827307 & 1 & & & \\
\hline X4 & 0,902747 & 0,786041 & 0,949344 & 0,900661 & 1 & & \\
\hline X5 & 0,758852 & 0,546898 & 0,740252 & 0,696453 & 0,787007 & 1 & \\
\hline $\mathrm{X} 6$ & 0,761314 & 0,893595 & 0,695939 & 0,924876 & 0,758369 & 0,774287 & 1 \\
\hline
\end{tabular}

The correlation matrix shows the level of influence of the selected factors on the object of study. According to it, the factors X1-X6 have the values of the correlation coefficients greater than 0.5 and are accepted for the study, however, among them, there is a multi-linearity above 0.7 . So, by correlation, multi- 
linearity observed in X1 with all factors except X5. For expediency of carrying out further modeling, $\mathrm{X} 5$ is accepted to the regression analysis as not correlating with $\mathrm{X} 1$ and $\mathrm{X} 4$, as an indicator with the greatest correlation with $\mathrm{Y}$.

The conducted regression analysis showed that almost $82,11 \%$ of Islamic Banking Assets depends on the formation and change of X4 and X5 values (Table 4). Fisher statistics characterize the significance of the regression model.

Table 4. Regression analysis of the economic model.

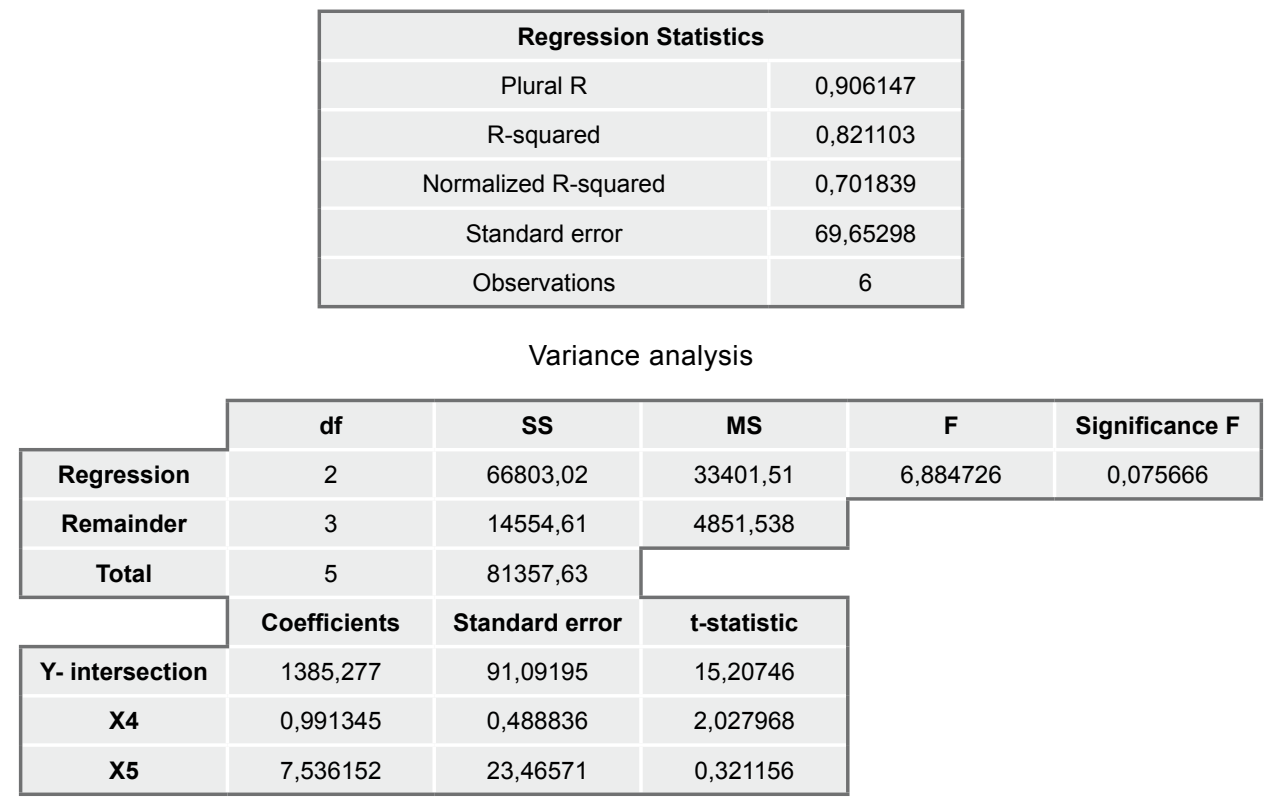

To forecast the value of Islamic banking assets, the regression equation (Formula $1)$ :

$$
\mathrm{Y}=1385,277+0,9914 * \mathrm{X} 4+7,5362 * \mathrm{X} 5
$$

After conducting a point forecast X4 and X5 and adding connected values in the regression equation (Formula 1), a forecast of the value of Islamic Banking Assets was made if it would be influenced only by X4 and X5. The point forecast is carried out through the determination of the trend line for each of the factors 
$\mathrm{X} 4$ and $\mathrm{X} 5$ for 1 forward forecast period with the conclusion of the regression equation. The forecast period number is supplied instead of the unknown $\mathrm{X}$ value.

Further, according to Formula 1, instead of the unknown X4 and X5, their predicted values for 2019-2021 are added to calculate the value of Y (Figure 3).

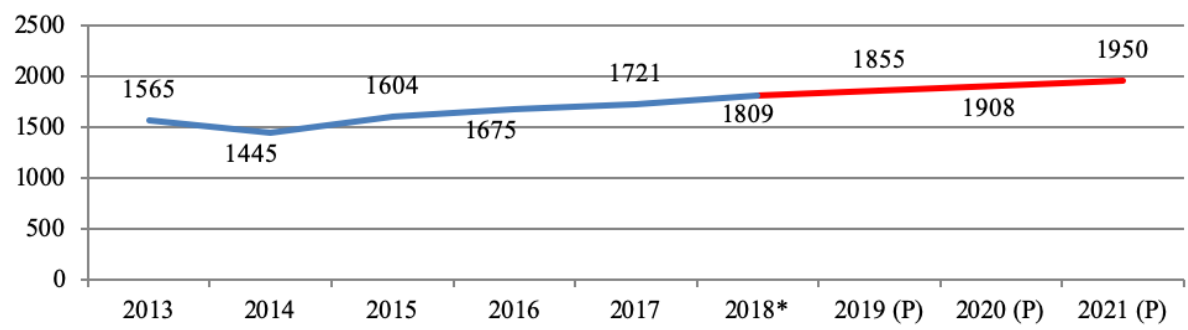

Figure 3. Forecast volume of Islamic Banking Assets the influence of factors $X 4$ and $X 5$, billion USD.

Thus, the impact on the Islamic banking Assets indicators such as global venture capital activity in FinTech with corporate participation (Deal count) (X4) and global private investment in blockchain \& cryptocurrency (Capital invested (\$B)) (X5) by 2021, may lead to an increase in the indicator to almost $\$ 2$ trillion.

An important aspect of the analysis is that Islamic banks are in a better position than traditional banks because they are a rapidly developing area of Islamic Finance. With enough investment in financial system participants in FinTech, can lead to more significant growth of the economy as a whole.

The most promising are such tools as crowdfunding, P2P lending, and digital technology management. The only factor that distinguishes the usual FinTech from the Islamic one is the need to observe the principles of Sharia.

Using the experience of upgrading existing financial instruments into products such as Murabaha and Musharaka that meet Sharia standards, it becomes possible to apply a similar approach to FinTech instruments. Combining safe investment and social responsibility with innovation and efficient use of available tools, Islamic Finance can use any modern financial instruments and use them effectively. 
For example, Islamic fiscal technology has solved astonishingly, with the appearing universal Islamic fiscal technology order fireplace stiffly on P2P financing. There is a basilar fireplace on peer-to-peer financing to address the remonstrative demand for making Shariah-compliant financing more available for commerce and consumers, but many slots stay self-relative to demand and market potential.

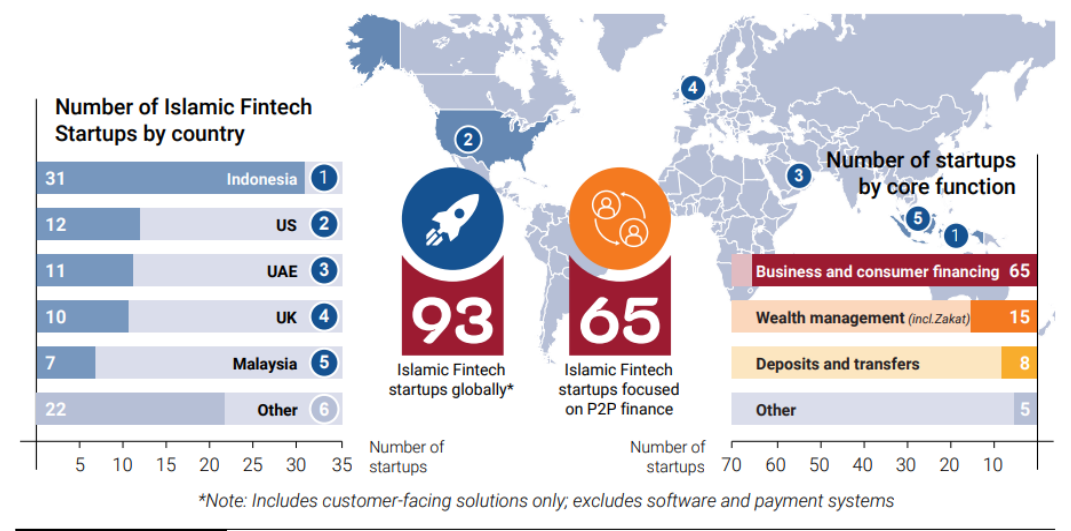

Key takeaway:

There is an emerging global Islamic Fintech ecosystem, with a strong focus to date on P2P finance.

Figure 4. Islamic FinTech Ecosystem. Source: (Islamic Fintech Report, 2018).

\section{CONCLUSION}

The previously described model of the influence of FinTech factors on Islamic banking Assets is proved in practice. To date, there are already dualistic companies that use FinTech and Islamic Finance at the same time (Table 5) (Firmansyah \& Anwar, 2019).

For example, InvestProperti.id is a sharia crowdfunding platform in Indonesia focusing on property investment. The vision of this firm is to provide ease to everyone to invest in property. With a tiny number of employees, since its establishment, InvestProperti.id is progressive as it has served 189 customers. 
Table 5. The profile of participating Islamic FinTech firms.

\begin{tabular}{|c|c|c|c|c|c|c|}
\hline No & $\begin{array}{c}\text { Name of the Fintech } \\
\text { firm }\end{array}$ & Headquarter & $\begin{array}{l}\text { The services } \\
\text { provided }\end{array}$ & $\begin{array}{c}\text { Year of } \\
\text { establishment }\end{array}$ & $\begin{array}{l}\text { Number of } \\
\text { employees }\end{array}$ & $\begin{array}{l}\text { Number of } \\
\text { customers }\end{array}$ \\
\hline 1 & $\begin{array}{l}\text { InvesProperti.id } \\
\text { (PT. Berkah Inovasi } \\
\text { Nusantara 2018) }\end{array}$ & Indonesia & $\begin{array}{l}\text { Crowdfunding } \\
\text { pltaform to } \\
\text { make property } \\
\text { investment } \\
\text { accessible to } \\
\text { everyone }\end{array}$ & 2018 & 3 & 189 \\
\hline 2 & $\begin{array}{l}\text { GOOLIVE (PT Sinergi } \\
\text { Inti Berkah Investama) }\end{array}$ & Indonesia & $\begin{array}{l}\text { Peer to peer } \\
\text { lending }\end{array}$ & 2018 & 5 & 67 \\
\hline 3 & $\begin{array}{l}\text { ALAMI Teknologi } \\
\text { Sharia }\end{array}$ & Indonesia & $\begin{array}{l}\text { Other financial } \\
\text { services } \\
\text { (Fintech } \\
\text { Aggregator) }\end{array}$ & 2017 & 9 & 9 \\
\hline 4 & $\begin{array}{c}\text { Syarfi (PT Syarfi } \\
\text { Teknologi Finansial) }\end{array}$ & Indonesia & $\begin{array}{l}\text { Peer to peer } \\
\text { lending }\end{array}$ & 2017 & 6 & \\
\hline 5 & $\begin{array}{l}\text { Qasir (PT Solusi } \\
\text { Teknologi Niaga) }\end{array}$ & Indonesia & $\begin{array}{l}\text { Application of } \\
\text { Point of Sales } \\
\text { (PoS) }\end{array}$ & 2015 & 44 & 5,000 \\
\hline 6 & $\begin{array}{l}\text { EthisCrowd (Ethis Pte } \\
\text { Ltd) }\end{array}$ & Singapore & $\begin{array}{l}\text { Real estate } \\
\text { investment }\end{array}$ & 2015 & 15 & 25,000 \\
\hline
\end{tabular}

Source: (Firmansyah \& Anwar, 2019).

Despite the slowdown in economic growth due to falling oil prices, the Islamic financial industry continues to evolve and strive for the same indicators. This is facilitated by "revolutionary" financial technology. The use of FinTech tools allows us to stimulate the economic growth of all countries of the world and not just Islamic ones.

On this basis, a new theoretical definition was formed, combining both aspects of the digital economy and Islamic finance. With the further formation of new tools that meet Shariah standards, but which are FinTech tools, the new conceptual apparatus can serve as a basis for a more precise definition of certain aspects of the Islamic FinTech industry.

The relevance of the application and development of the FinTech industry in the Islamic world is confirmed by the economic model of the forecast of Islamic banking assets when it is influenced by digital technology factors. This model also proves the development of dualistic companies combining FinTech and Islamic finance, as well as the rapid development of the Islamic FinTech Ecosystem. 


\section{ACKNOWLEDGEMENTS}

The work is performed according to the Russian Government Program of Competitive Growth of Kazan Federal University.

\section{REFERENCES}

Bloomberg, J. (2019). What is digitization? Retrieved from https://www. digital-adoption-hub.com/digitization-vs-digitalization-vs-digital-adoptionconfused-dont-be/

Bulatova, E., Zakhmatovm, D., Aliakberova, L.Z., \& Koczar, J. (2016). Key developments and trends in project finance market. Academy of Strategic Management fournal, 15, 185-190. Retrieved from https://www.questia.com/ library/journal/1P3-4207753101/key-developments-and-trends-in-projectfinance-market

Demyanova, E. A. (2017). Development of companies in modern conditions of introduction of financial technologies. Property relations in the Russian Federation, 7(190), 104-113.

Firmansyah, E. A., \& Anwar, M. (2019). Islamic financial technology (FINTECH): its challenges and prospect. In Achieving and Sustaining SDGs 2018 Conference: Harnessing the Power of Frontier Technology to Achieve the Sustainable Development Goals (ASSDG 2018). Atlantis Press.

Islami Bank Bangladesh Limited. (n.d.). Islamic Banking: Some Conceptual Issues. Retrieved from https://www.islamibankbd.com/abtIBBL/cis_islamic_ banking_some_conceptual_issues.php

Islamic Fintech Report. (2018). Current Landscape \& Path Forward. Dubai Islamic economy development center, Dinar Standard.

Jamaldeen, F. (n.d.). What Is Islamic Finance? Retrieved from https://www. dummies.com/personal-finance/islamic-finance/what-is-islamic-finance/ 
Li, J., Merenda, M., \& Venkatachan, A. R. (2009). Business Process Digitalization and New Product Development: An Empirical Study of Small and Medium-Sized Enterprises. International Fournal of E-Business Research, 5(1), 49-64. doi: https://doi.org/10.4018/jebr.2009010103

Lim, S. (2019). Islamic Banking. Retrieved from https://www.investopedia. com/terms/i/islamicbanking.asp

Mastoor, S. A. (2014). Islamic banking system in Afghanistan. In Proceedings of the Proceedings of the 10th International Academic Conference, Vienna, Fun 2014, pages 439-488. Retrieved from https://econpapers.repec.org/paper/ sekiacpro/0200302.htm

Patrutiu-Baltes, L. (2016). The Impact of Digitalization on Business Communication. SEA - Practical Application of Science, IV(2(11)), 319-325. Retrieved from http://seaopenresearch.eu/Journals/articles/SPAS_11_21. pdf

Pollari, I., \& Ruddenklau, A. (2018). The Pulse of Fintech 2018. Biannual global analysis of investment in fintech. Retrieved from https://assets.kpmg/content/ $\mathrm{dam} / \mathrm{kpmg} / \mathrm{xx} / \mathrm{pdf} / 2019 / 02 /$ the-pulse-of-fintech-2018.pdf

S\&P Dow Jones Indices. (n.d.). Dow Fones Islamic Market. Retrieved from https://us.spindices.com/index-family/shariah/dow-jones-islamic-market

World Data Atlas. (n.d.). Retrieved from https://knoema.ru/atlas 
Edición Especial Special Issue Octubre 2019 DOI: https://doi.org/10.17993/3ctic.2019.83-2.258-273 